\title{
PENGGUNAAN USER PERSONA UNTUK EVALUASI PENGALAMAN PENGGUNA LMS DAN MENGIDENTIFIKASI KEBUTUHAN PERANGKAT LUNAK
}

\author{
Arif Rahman Hidayatullah, Wahyu Andhyka Kusuma
}

Universitas Muhammadiyah Malang (UMM) Jawa Timur, Indonesia

Email: ar.hidayattullah12@gmail.com,wahyukusuma@umm.ac.id

\begin{tabular}{ll}
\hline INFO ARTIKEL & ABSTRAK \\
\hline Diterima & Learning Management System (LMS) merupakan salah satu \\
25 Agustus 2021 & media penunjang dari pembelajaran jarak jauh yang digunakan \\
Direvisi & di masa pandemi. Dalam meningkatkan pengalaman pengguna \\
05 September 2021 & LMS dan mengembangkan perangkat lunak, akan dilakukan \\
Disetujui & identifikasi kebutuhan sistem menggunakan metode User \\
15 September 2021 & Persona. Persona merupakan teknik Human Computer \\
\hline Kata Kunci: user & Interaction (HCI) yang akan memudahkan peneliti memahami \\
persona; HCI; LMS; & lebih dalam tentang bagaimana karakteristik dan variabel \\
sistem rekomendasi & prilaku pengguna. Penelitian ini bertujuan untuk menentukan \\
& informasi terkait karakteristik, kebutuhan pengguna pada \\
& perangkat lunak, sehingga menghasilkan data dari calon \\
& pengguna yang didasarkan dari hipotesa subjek terkait, yang \\
& kemudian akan dianalisa dan dijadikan sebagai acuan dalam \\
& melakukan proses pengembangan proyek perangkat lunak. \\
& Hasil dari penelitian ini adalah sistem rekomendasi yang \\
& terintegrasi dengan fitur penilaian. Fitur baru ini \\
& memungkinkan untuk memberikan informasi tentang \\
& kemampuan mahasiswa berdasarkan penilaian yang sudah \\
& didapatkan. Informasi tersebut berupa saran bidang minat yang \\
& sesuai dengan masing-masing kemampuan mahasiswa, \\
& berdasarkan penilaian terhadap mata kuliah yang relevan \\
dengan masing-masing bidang minat yang selanjutnya & diimplementasikan menggunakan use case diagram.
\end{tabular}

\section{ABSTRACT}

The Learning Management System (LMS) is one of the supporting media for distance learning used during the pandemic. In improving the LMS user experience and developing software, system requirements will be identified using the User Persona method. Persona is a Human Computer Interaction (HCI) technique that will make it easier for researchers to understand more deeply about the characteristics and variables of user behavior. This study aims to determine information related to the characteristics and

How to cite:

E-ISSN:

Published by:
Hidayatullah, A. R., \& Kusuma, W. A. (2021) Penggunaan User Persona untuk Evaluasi Pengalaman Pengguna LMS dan Mengidentifikasi Kebutuhan Perangkat Lunak. Jurnal Syntax Admiration 2(9). https://doi.org/10.46799/jsa.v2i9.301 2722-5356

Ridwan Institute 
needs of users on the software, so as to produce data from potential users based on the hypothesis of the related subject, which will then be analyzed and used as a reference in carrying out the software project development process. The result of this research is a recommendation system that is integrated with the assessment feature. This new feature makes it possible to provide information about student abilities based Keywords: $\quad$ user on the assessments that have been obtained. The information is personas; HCI; in the form of suggestions for areas of interest that are in LMS; accordance with each student's ability, based on an assessment recommendation of the courses relevant to each area of interest which are then system implemented using use case diagrams.

\section{Pendahuluan}

Pandemi Covid-19 yang tersebar hampir di seluruh dunia memberikan dampak dan tantangan tersendiri terhadap sektor pendidikan yang ada di Indonesia, khususnya perguruan tinggi (Sumantyo, 2020). Sejak Covid-19 masuk ke Indonesia, Kemendikbud mengeluarkan keputusan untuk tidak melakukan pembelajaran secara tatap muka, melainkan pembelajaran jarak jauh (PJJ) yang memanfaatkan sistem e-learning (Sumantyo, 2020). Beberapa perguruan tinggi merespons dari putusan yang diambil oleh Kemendibuk, termasuk Universitas Muhammadiyah Malang. Sejak larangan pembelajaran secara tatap muka dikeluarkan oleh Kemendikbud, Universitas Muhammadiyah Malang memberlakukan perkuliahan secara daring yaitu dengan menggunakan platform LMS (Learning Management System), Canvas, Google Classroom, Edmodo, dan lain-lain.

LMS merupakan sistem yang banyak digunakan oleh universitas dalam melakukan pembelajaran jarak jauh. LMS berfungsi untuk memberikan sebuah materi, mendukung kolaborasi, menilai kinerja mahasiswa, dan menghasilkan laporan yang berguna untuk memaksimalkan efektivitas pembelajaran jarak jauh (Putra et. al 2020). Mahasiswa dapat mengakses materi perkuliahan serta mengakses tugas yang diberikan dosen melalui LMS (Suhardi and Hariawan 2020). Penggunaan LMS sebagai media pembelajaran jarak jauh diharapkan dapat membantu tercapainya tujuan pendidikan (Putra et al., 2020). Sistem LMS yang digunakan oleh UMM saat ini menggunakan program Moodle, yang memungkinkan dosen dan mahasiswa dapat melakukan kegiatan belajar mengajar dimana saja dan kapan saja.

Dalam mengidentifikasi sebuah sistem, diperlukan pendekatan dengan pengguna untuk mengetahui kebutuhan yang diperlukan. Oleh karena itu peneliti menggunakan HCI yang akan berinteraksi dengan User Persona untuk memenuhi kebutuhan identifikasi (Warin et al. 2018). Penggunaan metode persona yang ada di HCI diharapkan bisa mendapatkan informasi yang realistis dan representatif yang mencakup detail fiksi untuk karakteristik pengguna yang lebih kompleks. Komposisi persona dapat didasarkan pada informasi yang dibayangkan, fitur demografis, dan biografi dari persona yang digambarkan. Persona merupakan teknik HCI, yaitu proses untuk 
mendukung pendekatan dalam karakteristik user selama tahap rekayasa kebutuhan (Kusuma et al. 2021). Pada penelitian terdahulu metode persona diimplementasikan untuk membangun sebuah sistem dan mampu menghasilkan karakteristik selama user berinteraksi dengan sistem tersebut (Zagallo et al., 2019).

Teknik ini berfokus untuk membantu analisis dan desain perangkat lunak yang kemudian fitur dan sasarannya diperuntukkan untuk pengguna. Namun teknik $H C I$ masih memiliki kekurangan, yaitu tidak memiliki definisi rinci tentang aktifitas dan produk (Kusuma et al. 2021). Selain itu, banyak pengembang dalam prakteknya tidak memperhatikan persyaratan teori (Shekhar \& Marsden, 2018). Oleh karena itu, penelitian ini menambahkan metode persona sebagai pelengkap dari teknik $H C I$, sehingga $H C I$ tidak hanya memiliki pemahaman tentang kebutuhan dan sasaran user, tetapi juga pemahaman mengenai karakteristik dan kemampuan user untuk merancang dan menerapkan sistem yang dapat digunakan (Ferreira et al., 2018). Persona adalah karakter fiksi yang mewakili karakteristik utama dari pengguna produk tertentu (Zagallo et al., 2019). Persona tersebut didasarkan pada data dari pengguna produk yang sebenarnya (Zagallo et al., 2019). Pencetus dari persona adalah Alan Cooper yang menggunakannya sebagai sistem untuk menyalurkan, mengklarifikasi, dan memahami tujuan dan minat pengguna (Shekhar \& Marsden, 2018).

Terdapat beberapa penelitian terdahulu yang berkaitan dengan user persona. Penelitian (Kusuma, Ashari, et al., 2021) membahas tentang pengembangan sistem UMMBimskrip. UMMBimskrip adalah sebuah sistem perangkat lunak yang dapat memudahkan mahasiswa untuk menentukan jadwal bimbingan dan report hasil bimbingan. Sistem ini dikembangkan dengan menggunakan user persona untuk mengidentifikasi kebutuhan mahasiswa. Jika pada penelitian tersebut menjelaskan 10 tahap dan validasi, berbeda dengan penelitian ini yang menjelaskan 5 tahap dan melakukan validasi menggunakan tahap storytelling. Selain penelitian (Kusuma, Ashari, et al., 2021), juga terdapat penelitian terdahulu yang menggunakan metode user persona yang bisa dilihat pada tabel 1 .

Pada penelitian ini, studi kasus yang diangkat adalah sistem penilaian pada $L M S$ yang kemudian akan dikembangkan menjadi data dan informasi yang dapat digunakan oleh mahasiswa sebagai acuan dalam menentukan bidang minat atau peminatan yang sesuai. Peminatan merupakan suatu keputusan mahasiswa untuk menentukan kelompok mata kuliah yang sesuai minat, bakat, dan kemampuan (Alifa \& Utami, 2017). Permasalahan yang terjadi selama ini adalah banyak mahasiswa yang mengalami kesulitan dalam menentukan bidang minat yang sesuai dengan kemampuannya. Dengan menggunakan metode user persona diharapkan bisa mengidentifikasi kebutuhan pengguna perihal sistem penilaian yang sudah ada dan bagaimana cara mengembangkannya. 
Tabel 1

Penelitian Sebelumnya

\begin{tabular}{|c|c|c|c|c|}
\hline $\begin{array}{c}\text { Judul } \\
\text { Penelitian }\end{array}$ & Penulis \& Tahun & Metode & $\begin{array}{c}\text { Hasil } \\
\text { Penelitian }\end{array}$ & $\begin{array}{c}\text { Perbedaan dengan } \\
\text { penelitian ini }\end{array}$ \\
\hline $\begin{array}{l}\text { Elisitasi } \\
\text { kebutuhan } \\
\text { perangkat } \\
\text { lunak dengan } \\
\text { metode } \text { user } \\
\text { persona } \\
\text { dalam upaya } \\
\text { meningkatkan } \\
\text { pengalaman } \\
\text { pengguna }\end{array}$ & $\begin{array}{l}\text { Wahyu Andhyka } \\
\text { Kusuma, Nirma } \\
\text { Dwi Wulansari, } \\
\text { Moch. Ilham } \\
\text { Fakhriansyah. } \\
\text { Tahun } 2020\end{array}$ & $\begin{array}{l}\text { User } \\
\text { Persona }\end{array}$ & $\begin{array}{l}\text { Sistem } \\
\text { UMMBimskri } \\
\text { p untuk } \\
\text { memudahkan } \\
\text { mahasiswa } \\
\text { dalam } \\
\text { menentukan } \\
\text { jadwal } \\
\text { bimbingan }\end{array}$ & $\begin{array}{l}\text { Penelitian ini } \\
\text { menggunakan } 5 \\
\text { tahap. Validasi } \\
\text { dilakukan pada tahap } \\
\text { storytelling. }\end{array}$ \\
\hline $\begin{array}{l}\text { Through the } \\
\text { Eyes of } \\
\text { Faculty: } \\
\text { Using } \\
\text { Personas as a } \\
\text { Tool for } \\
\text { Learner- } \\
\text { Centered } \\
\text { Professional } \\
\text { Development }\end{array}$ & $\begin{array}{l}\text { Patricia Zagallo, } \\
\text { Jill McCourt, } \\
\text { Robert Idsardi, } \\
\text { Michelle K. } \\
\text { Smith, Mark } \\
\text { Urban-Lurain, } \\
\text { Tessa C. } \\
\text { Andrews, Kevin } \\
\text { Haudek, Jennifer } \\
\text { K. Knight, John } \\
\text { Merrill, Ross } \\
\text { Nehm, Luanna B. } \\
\text { Prevost, and } \\
\text { Paula P. Lemons. } \\
\text { Tahun } 2019\end{array}$ & $\begin{array}{l}\text { User } \\
\text { Persona }\end{array}$ & $\begin{array}{l}\text { Penggunaan } \\
\text { persona oleh } \\
\text { fasilitator } \\
\text { professional } \\
\text { development } \\
\text { untuk } \\
\text { menentukan } \\
\text { cara } \\
\text { mendekati } \\
\text { peserta didik } \\
\text { mereka. }\end{array}$ & $\begin{array}{l}\text { Pada penelitian } \\
\text { (Zagallo et al., 2019), } \\
\text { mereka menggunakan } \\
\text { enam tahap milik } \\
\text { Pruitt dan Adlin } \\
\text { (2006) dalam } \\
\text { membuat user } \\
\text { persona. }\end{array}$ \\
\hline $\begin{array}{l}\text { Elisitasi } \\
\text { Kebutuhan } \\
\text { Sistem } \\
\text { Laboratorium } \\
\text { Informatika } \\
\text { Universitas } \\
\text { Muhammadiy } \\
\text { ah Malang } \\
\text { Menggunakan } \\
\text { Pendekatan } \\
\text { User Persona }\end{array}$ & $\begin{array}{l}\text { Denar Regata } \\
\text { Akbi, Wahyu } \\
\text { Andhyka } \\
\text { Kusuma, Andi } \\
\text { Syahrial Lathifi, } \\
\text { Azmi, Abdul } \\
\text { Jabbar Nur Ihsan. } \\
\text { Tahun } 2020\end{array}$ & $\begin{array}{l}\text { User } \\
\text { Persona }\end{array}$ & $\begin{array}{l}\text { Sistem } \\
\text { notifikasi } \\
\text { berbasis } \\
\text { mobile untuk } \\
\text { menjadi } \\
\text { pemberi } \\
\text { informasi } \\
\text { seputar } \\
\text { praktikum. }\end{array}$ & $\begin{array}{l}\text { Penelitian ini } \\
\text { menggunakan } \\
\text { interview dan } \\
\text { storytelling untuk } \\
\text { memvalidasi dan } \\
\text { menyimpulkan. }\end{array}$ \\
\hline $\begin{array}{l}\text { Technique for } \\
\text { representing } \\
\text { requirements } \\
\text { using } \\
\text { personas: a } \\
\text { controlled } \\
\text { experiment }\end{array}$ & $\begin{array}{l}\text { Bruna Ferreira, } \\
\text { Williamson Silva, } \\
\text { Simone D.J. } \\
\text { Barbosa, Tayana } \\
\text { Conte }\end{array}$ & $\begin{array}{l}\text { Living } \\
\text { Persona }\end{array}$ & $\begin{array}{l}\text { Penggunaan } \\
\text { teknik baru } \\
\text { PATHY lebih } \\
\text { efisien jika } \\
\text { dibandingkan } \\
\text { dengan teknik } \\
\text { Acuña et al. }\end{array}$ & $\begin{array}{l}\text { Teknik Pathy lebih } \\
\text { berfokus dengan fitur } \\
\text { aplikasi yang akan } \\
\text { dikembangkan. } \\
\text { Sedangkan penelitian } \\
\text { ini berfokus terhadap } \\
\text { kebutuhan user. }\end{array}$ \\
\hline
\end{tabular}




\begin{tabular}{|c|c|c|c|c|}
\hline $\begin{array}{l}\text { Living } \\
\text { Persona } \\
\text { Technique } \\
\text { applied to } \\
\text { HCI } \\
\text { Education }\end{array}$ & $\begin{array}{l}\text { Bruno Warin, } \\
\text { Christophe } \\
\text { Kolski, Toffolon } \\
\text { Claudine. } \\
\text { Tahun } 2018\end{array}$ & $\begin{array}{l}\text { Living } \\
\text { Persona }\end{array}$ & $\begin{array}{l}\text { Implementasi } \\
\text { teknik Living } \\
\text { Persona } \\
\text { dalam } \\
\text { skenario } \\
\text { pedagogis } \\
\text { yang } \\
\text { diterapkan } \\
\text { pada latihan } \\
\text { mengajar } \\
\text { dalam sistem } \\
\text { interaktif. }\end{array}$ & $\begin{array}{l}\text { Pada penelitian ini } \\
\text { penggalihan } \\
\text { kebutuhan dilakukan } \\
\text { dengan cara } \\
\text { wawancara. } \\
\text { Sedangkan pada } \\
\text { penelitian (Warin et } \\
\text { al., 2018) } \\
\text { menggunakan } \\
\text { kueisioner. }\end{array}$ \\
\hline
\end{tabular}

\section{Metode Penelitian}

\section{Storyboard}

Dalam mengembangkan sebuah sistem, storyboard dapat digunakan untuk mengidentifikasi konsekuensi potensial yang mungkin dihadapi pengguna dengan aplikasi di masa mendatang (Palacin-Silva et al., 2017). Storyboard juga dapat digunakan sebagai media yang efektif untuk menangkap dan mengeksplorasi pengalaman pengguna dengan menerjemahkan cerita dan naskah ke dalam adegan melalui siapa, apa, kapan, dan bagaimana menggunakan gambar dan teks (PalacinSilva et al., 2017).

\section{Interview}

User Persona melengkapi metode kuantitatif dan kualitatif untuk meningkatkan komunikasi dengan stakeholder yang berkepentingan (Bruno Warin et al., 2018). Salah satu langkah kunci dalam metode pengembangan persona adalah membutuhkan operasionalisasi dan segmentasi data kualitatif seperti wawancara terbuka (Korsgaard et al., 2020).

\section{Storytelling}

Setelah melakukan interview atau wawancara, pada tahap ini akan dilakukan pengecekan dan validasi dari variabel yang sudah dipilih. Untuk memeriksa kelengkapan terkait kebutuhan pengguna, dilakukan diskusi dengan stakeholder (Wolf, 2017). Kemudian akan diberikan beberapa pertanyaan untuk melengkapi validasi yang kurang (Wolf, 2017).

\section{User Persona}

Tahap ini akan mendeskripsikan persona yang telah di wawancarai dengan membuat narasi singkat yang menggambarkan kepribadian (Struktur psikologis seperti identitas, status, tujuan, dan pengalaman) (Kusuma, Nurhuda, et al., 2021). Kemudian akan dipilih persona yang diprioritaskan untuk menentukan mana yang harus menjadi target pengembangan utama (Kusuma, Nurhuda, et al., 2021). Memahami persona adalah faktor penting untuk memenuhi kebutuhan stakeholder (Ferreira et al., 2018). Untuk menciptakan empati, persona ditampilkan seolah-olah mereka adalah orang sungguhan, misalnya dengan foto dan bagian termasuk hobi dan keterampilan latar belakang (Shekhar \& Marsden, 2018). Pada tahap ini peneliti 
akan menanyakan konstruksi profil setiap persona menggunakan pertanyaan hipotesis (White et al., 2021).

\section{Use Case}

Persona yang dikumpulkan dapat diintegrasikan ke model use case (Spiliotopoulos et al., 2020). Pembuatan use case dilakukan dengan mempertimbangkan hubungan atau relasi antara pola dan mekanisme kegunaan. Use case memiliki proses yang dapat memetakan model kerangka kerja persona (Kusuma et al., 2021). Model use case yang dibuat bisa dari hasil revisi atau adapatasi untuk membuat use case yang lebih kompak (Spiliotopoulos et al., 2020).

\section{Hasil dan Pembahasan}

\section{A. Storyboard}

Pada tahap ini dibuat storyboard dari proses pembuatan sistem $L M S$. Tujuan di buatnya storyboard adalah untuk mendeskripsikan semua aktivitas yang dapat dilakukan oleh pengguna di dalam sistem (Syahrul \& Pertiwi, 2020). Berdasarkan aktifitas-aktifitas tersebut, maka dilakukan penggalian kebutuhan mahasiswa dalam menggunakan sistem $L M S$. Semua proses atau alur dari tahapan pengembangan sistem $L M S$ dapat dilihat pada storyboard yang digambarkan pada Gambar 1 dan 2.

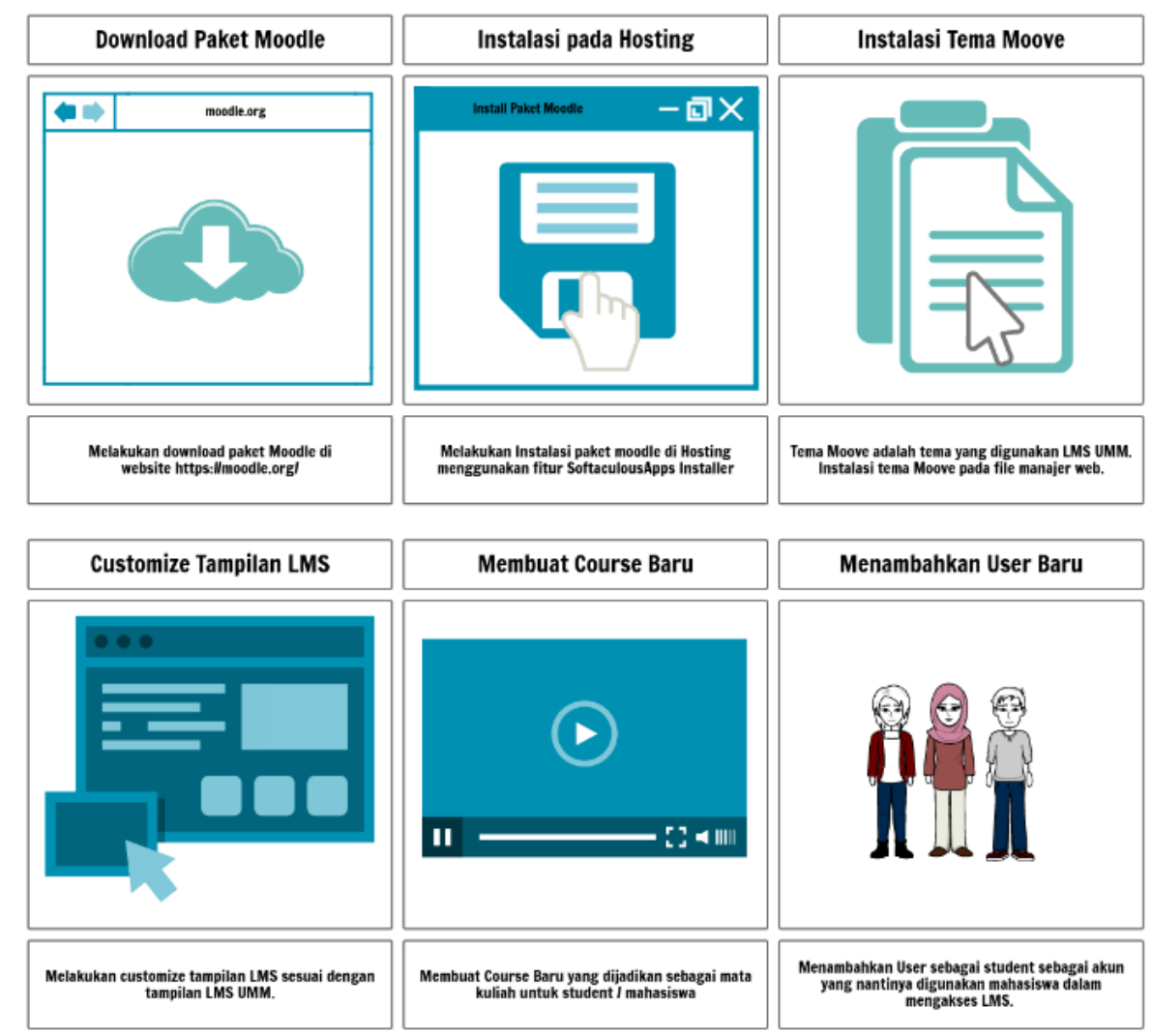

Gambar 1

Storyboard Pengembangan LMS 


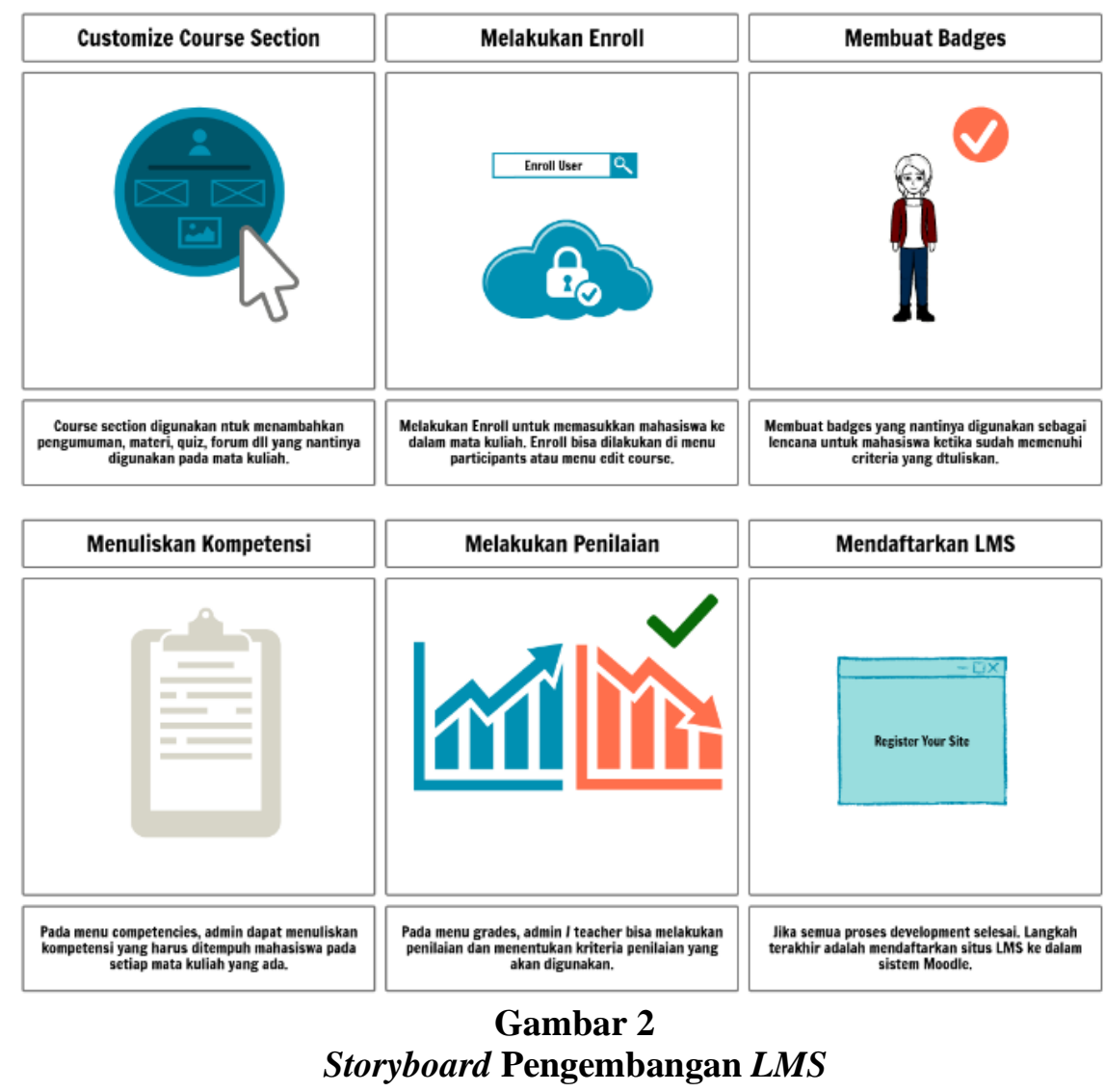

Salah satu fitur yang berfungsi untuk mengukur kompetensi mahasiswa pada $L M S$ adalah fitur penilaian. Fitur tersebut memungkinkan seorang dosen memberikan penilaian terhadap materi atau tugas yang sudah diselesaikan oleh mahasiswa. Namun masih banyak dosen yang belum menggunakan fitur tersebut. Dimana hal itu mengakibatkan mahasiswa tidak mengetahui kemampuan atau pencapaian dari tugas atau materi yang sudah diberikan oleh dosen. Berdasarkan storyboard pada Gambar 2, dituliskan bahwa salah satu tahapan implementasi LMS adalah dosen melakukan penilaian dan menentukan kriteria penilaian yang akan digunakan.

Salah satu dampak akibat dari ketidaktahuan mahasiswa terhadap kemampuannya sendiri adalah mahasiswa akan kesulitan dalam menentukan bidang minat atau peminatan yang ada di semester enam. Permasalahan ini menjadikan mahasiswa ikut-ikutan temannya dalam menentukan bidang minat atau peminatan. Tentunya hal ini akan menyebabkan mahasiswa salah dalam memilih bidang minat dan akan merugikan mahasiswa itu sendiri. Selain ketidaktahuan mahasiswa terhadap kemampuannya, keterbatasan informasi yang dimiliki mahasiswa dari setiap bidang minat yang ada juga menjadi penyebab mahasiswa kesulitan dalam menentukan bidang minat. 


\section{B. Interview}

Pada tahap ini dilakukan interview atau wawancara terhadap stakeholder yang terlibat dalam penggunaan sistem $L M S$ yaitu mahasiswa prodi Informatika UMM. Dalam menentukan jumlah stakeholder yang terlibat, penelitian ini menggunakan rumus Nielsen. Dimana jumlah responden yang ikut serta yaitu sebanyak 5 mahasiswa. Wawancara dilakukan kepada stakeholder yang merupakan mahasiswa informatika Universitas Muhammadiyah Malang. Wawancara dilakukan secara Synchronous menggunakan Google Meet dan direkam dalam bentuk audio / video. Rekaman audio / video digunakan untuk meninjau keakuratan dari hasil wawancara tersebut (Boser et al., 2020). Selain itu, rekaman juga digunakan untuk mengamati tanggapan yang diberikan secara berulang (Boser et al., 2020).

Pada penggalian kebutuhan yang dilakukan pada tahap storyboard dihasilkan enam variabel yang kemudian diberikan kepada stakeholder pada tahap wawancara. Variabel tersebut digunakan untuk mengukur bagaimana kepuasan mahasiswa dalam menggunakan LMS dan kepuasan mahasiswa terhadap dosen. Dari hasil wawancara yang dilakukan, didapatkan hasil berupa persentase dengan skala tinggi dan rendah. Dimana skala tersebut diperoleh dari hasil wawancara mahasiswa dengan jawaban "ya" atau "tidak". Hasil dari persentase bisa dilihat pada tabel 2:

Tabel 2

Hasil Wawancara

\begin{tabular}{lcc}
\hline \multicolumn{1}{c}{ variabel } & skala & persentase(\%) \\
\hline Tingkat Kepuasan Mahasiswa & Tinggi & 20 \\
\cline { 2 - 3 } Terhadap Fitur Nilai di LMS & Rendah & 80 \\
\hline $\begin{array}{l}\text { Tingkat Kepuasan Mahasiswa } \\
\text { Terhadap Dosen yang }\end{array}$ & Tinggi & 20 \\
\cline { 2 - 3 } $\begin{array}{l}\text { Memberikan Nilai Secara } \\
\text { Update }\end{array}$ & Rendah & 80 \\
\hline $\begin{array}{l}\text { Mahasiswa yang belum } \\
\text { mengetahui kemampuannya. }\end{array}$ & Tinggi & 80 \\
\cline { 2 - 3 } $\begin{array}{l}\text { Mahasiswa yang memahami } \\
\text { setiap bidang minat yang ada. }\end{array}$ & Rendah & 20 \\
\hline $\begin{array}{l}\text { Mahasiswa yang bimbang } \\
\text { dalam menentukan bidang } \\
\text { minat yang sesuai. }\end{array}$ & Rendah & 60 \\
\hline $\begin{array}{l}\text { Mahasiswa yang ikut-ikutan } \\
\text { teman dalam memilih bidang } \\
\text { minat. }\end{array}$ & Tinggi & 100 \\
\cline { 2 - 3 } & Rendah & 0.00 \\
\hline
\end{tabular}

\section{Storytelling}

Dari hasil interview yang diperoleh pada tahap sebelumnya, didapatkan bahwa fitur penilaian yang ada di $L M S$ belum digunakan secara maksimal oleh dosen. Hal itu dikarenakan dosen belum memberikan penilaian secara update terhadap mahasiswa. Dimana hal itu menyebabkan mahasiswa tidak mengetahui kemampuan 
atau pencapaian dari tugas atau materi yang sudah diberikan oleh dosen. Selain ketidakpahaman tentang kemampuan, minimnya informasi mengenai bidang minat membuat 2 dari 5 mahasiswa tidak memahami setiap bidang minat yang ada. Ketidaktahuan kemampuan dan minimnya informasi menyebabkan 5 dari 5 mahasiswa yang di interview mengalami kebimbangan dalam menentukan bidang minat. Hal itu menyebabkan 1 dari 5 mahasiswa ikut-ikutan dalam menentukan bidang minat.

\section{User Persona}

Dalam membuat user persona diharapkan dapat mendapatkan segmentasi pengguna yang baik. Dengan tujuan untuk mengetahui kebutuhan, karakteristik, atau perilaku yang berbeda-beda dari masing-masing stakeholder. Untuk mendapatkan segmentasi pengguna yang baik maka akan dilakukan wawancara terhadap masingmasing stakeholder. Kemudian dari hasil wawancara yang sudah dilakukan pada tahap interview, akan digunakan untuk mengetahui kebutuhan dari keseluruhan user. Lalu akan dibuat persona type dari keseluruhan user yang kemudian akan dipilih salah satu dan dijadikan sebagai primary persona untuk mewakili seluruh user yang ada (Kusuma, Ashari, et al., 2021). Pada tahap ini akan dibuat sebuah cerita yang menggambarkan persona type seperti pada gambar 3 yang menjadi deskripsi singkat dari subjek.

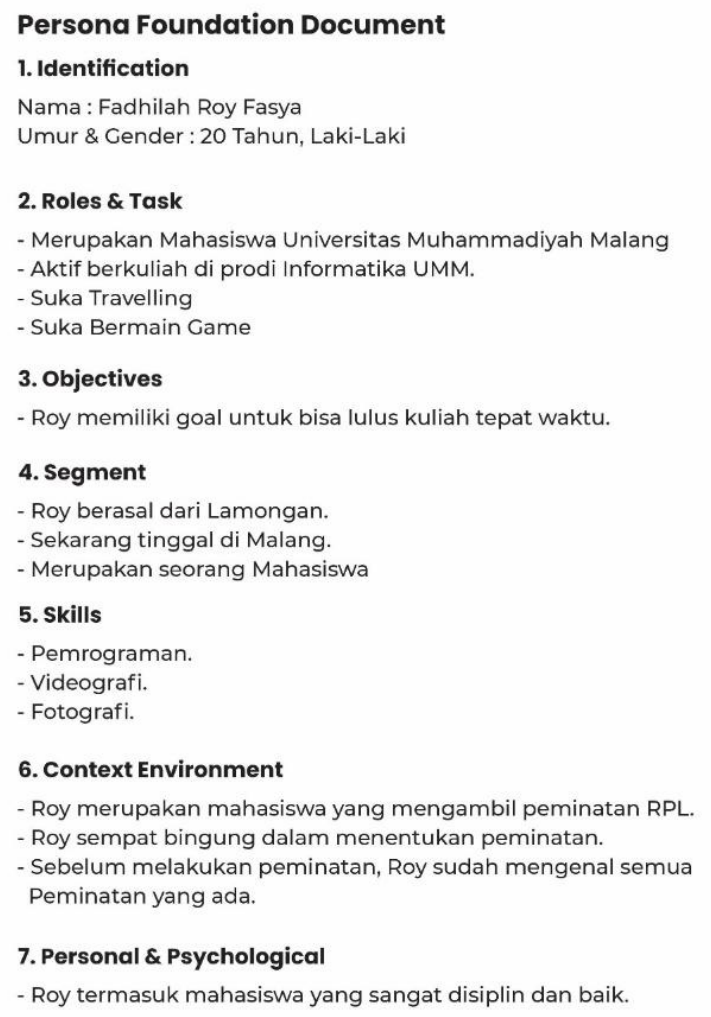

Gambar 3

Persona Foundation Document 
Dari data pada gambar 3 kemudian akan dipilih data dari subjek yang paling optimal. Data tersebut akan menjadi referensi utama dalam mengembangkan aplikasi (Issn et al., 2020). Hal ini memungkinkan stakeholder atau calon pengguna tidak harus selalu ada di saat peneliti membutuhkan data tertentu karena sudah diwakili oleh persona yang sudah dibuat (Issn et al., 2020). Mendesain tampilan Persona sangat penting untuk menyampaikan representasi yang realistis dan kaya dari persona (White et al., 2021).

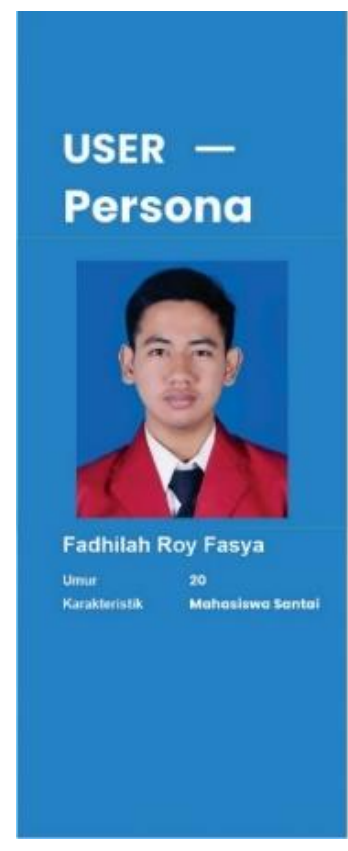

\section{E. Membuat Use Case}

Untuk mempermudah melakukan tahapan-tahapan kegiatan maka dibuat diagram use case sebagai pemodelan apa saja yang dapat dilakukan aplikasi (Rabbanii et al., 2019). Maka dibuat use case seperti pada gambar 5 dari sistem yang akan dikembangkan. Use case dibentuk berdasarkan pada kebutuhan user yang diperoleh pada tahap storytelling. Dimana kebutuhan mahasiswa mengenai ketidaktahuan kemampuan mahasiswa dipresentasikan pada use case melihat nilai tugas dan nilai akhir matkul. Sedangkan kebutuhan mahasiswa mengenai kesulitan dalam menentukan bidang minat dipresentasikan pada use case melihat saran peminatan. 


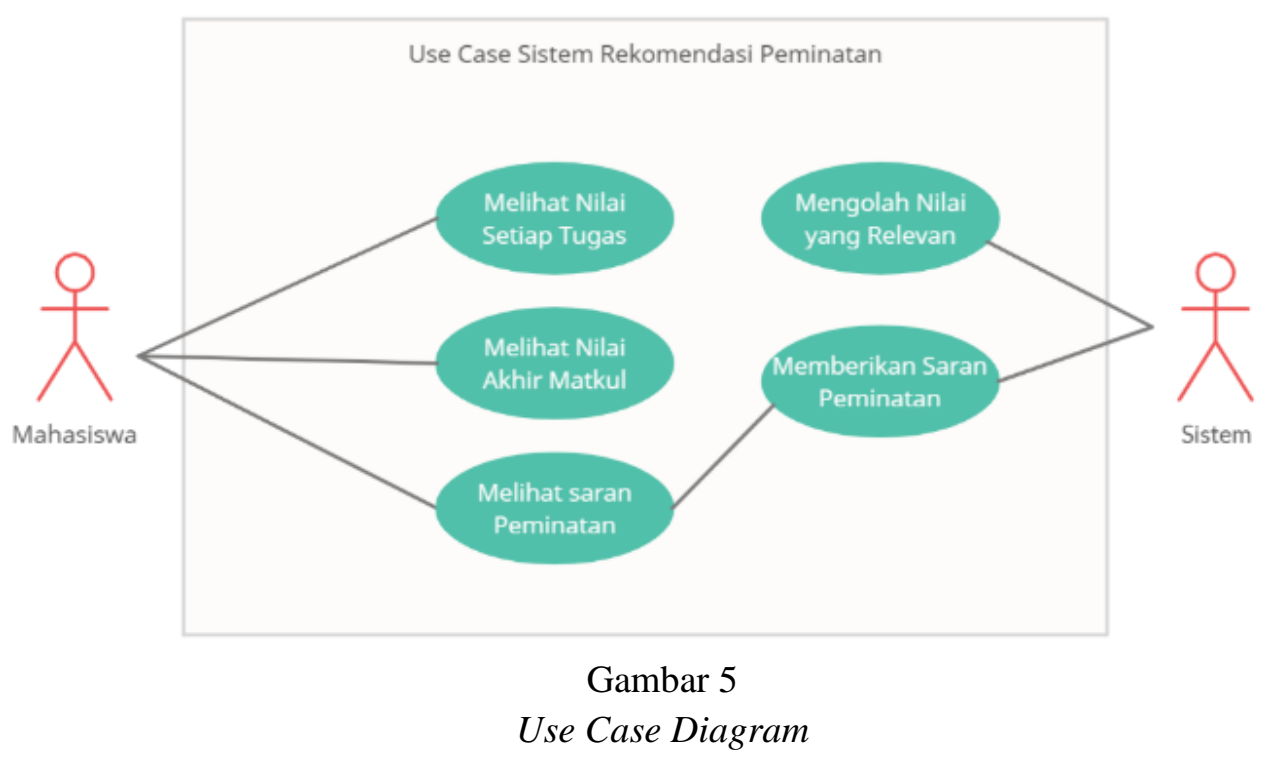

Use case merupakan gambaran dari sebuah perangkat lunak. Dimana use case berfungsi untuk memberi tahu apa yang akan dilakukan system ketika berkomunikasi dengan pengguna (Fitriana, 2020).

\section{Kesimpulan}

Dari penelitian yang sudah dilakukan dengan menggunakan user persona untuk mengevaluasi pengalaman pengguna $L M S$ diperoleh informasi bahwa dosen belum maksimal dalam menggunakan fitur penilaian di lms. Hal itu berpengaruh terhadap ketidaktahuan mahasiswa mengenai kemampuan dan pencapaian dari tugas atau materi yang sudah diberikan oleh dosen. Ketidaktahuan mahasiswa terhadap kemampuannya berpengaruh terhadap kesulitan mahasiswa dalam menentukan bidang minat. Selain ketidaktahuan kemampuan, minimnya informasi mengenai bidang minat juga menjadi faktor pendukung mahasiswa kesulitan menentukan bidang minat.

Dari serangkaian metode yang sudah dilakukan menghasilkan sebuah kebutuhan perangkat lunak yang dapat membantu mahasiswa dalam menentukan bidang minat. Hasil dari penelitian ini adalah dapat dikembangkan sebuah sistem rekomendasi yang terintegrasi dengan fitur penilaian. Fitur baru ini memungkinkan untuk memberikan informasi tentang kemampuan mahasiswa berdasarkan penilaian yang sudah didapatkan. Informasi tersebut berupa saran bidang minat yang sesuai dengan masingmasing kemampuan mahasiswa, berdasarkan penilaian terhadap mata kuliah yang relevan dengan masing-masing bidang minat. 


\section{BIBLIOGRAFI}

Alifa, F., \& Utami, A. W. (2017). Rancang Bangun Sistem Pendukung Keputusan Peminatan Mata Kuliah Menggunakan Metode Weighted Product. Jurnal Manajemen Informatika, Volume 08 (01), 20-28. Google Scholar

Boser, Q. A., Dawson, M. R., Schofield, J. S., Dziwenko, G. Y., \& Hebert, J. S. (2020). Defining the design requirements for an assistive powered hand exoskeleton: A pilot explorative interview study and case series. Prosthetics and Orthotics International. https://doi.org/10.1177/0309364620963943. Google Scholar

Ferreira, B., Silva, W., Barbosa, S. D. J., \& Conte, T. (2018). Technique for representing requirements using personas: A controlled experiment. IET Software, 12 (3), 280-290. https://doi.org/10.1049/iet-sen.2017.0313. Google Scholar

Fitriana, G. F. (2020). Pengujian Aplikasi Pengenalan Tulisan Tangan menggunakan Model Behaviour Use case. Jatisi (Jurnal Teknik Informatika Dan Sistem Informasi), 7 (2), 200-213. Google Scholar

Issn, I. P. E.-, Versi, D. I. B., Siyamto, Y., \& Saputra, A. (2020). Computer Based Information System Journal Perancangan Aplikasi Keuangan Berbasis Android. 02, 60-67. Google Scholar

Korsgaard, D., Bjørner, T., Sørensen, P. K., \& Burelli, P. (2020). Creating user stereotypes for persona development from qualitative data through semi-automatic subspace clustering. User Modeling and User-Adapted Interaction, 30 (1), 81-125. https://doi.org/10.1007/s11257-019-09252-5. Google Scholar

Kusuma, W. A., Ashari, M. R., Oktaviani, C. D., \& Na'im, A. N. (2021). Penggunaan User Persona Untuk Evaluasi Dan Meningkatkan Ekspektasi Pengguna Dalam Kebutuhan Perangkat Lunak. Prosiding Sentra (Seminar Teknologi Dan Rekayasa), 6, 171-183. Google Scholar

Kusuma, W. A., Nurhuda, M. A., \& Purwanto, W. D. (2021). Peningkatan Pemahaman Pengguna Pada Proses Penggalian Kebutuhan Menggunakan Metode Persona. Prosiding Sentra (Seminar Teknologi Dan Rekayasa), 6, 184-193. Google Scholar

Palacin-Silva, M., Khakurel, J., Happonen, A., Hynninen, T., \& Porras, J. (2017). Infusing Design Thinking into a Software Engineering Capstone Course. Proceedings - 30th IEEE Conference on Software Engineering Education and Training, CSEE and T 2017, 2017-Janua 212-221. Google Scholar

Putra, E. A., Sudiana, R., \& Pamungkas, A. S. (2020). Pengembangan Smartphone Learning Management System (S-LMS) Sebagai Media Pembelajaran Matematika di SMA. Kreano, Jurnal Matematika Kreatif-Inovatif, 11 (1), 36-45. Google Scholar 
Rabbanii, I., Brata, A. H., \& Brata, K. C. (2019). Penerapan Metode Lean UX pada Pengembangan Aplikasi Bill Splitting menggunakan Platform Android. Jurnal Pengembangan Teknologi Informasi Dan Ilmu Komputer E-ISSN, 2548, 964X. Google Scholar

Shekhar, A., \& Marsden, N. (2018). Cognitive walkthrough of a learning management system with gendered personas. ACM International Conference Proceeding Series, 191-198. Google Scholar

Spiliotopoulos, D., Margaris, D., \& Vassilakis, C. (2020). Data-assisted persona construction using social media data. Big Data and Cognitive Computing, 4 (3), 114. Google Scholar

Sumantyo, F. D. S. (2020). Pendidikan Tinggi di Masa dan Pasca Covid-19. Jurnal Kajian Ilmiah, 1 (1), 81-92. https://doi.org/10.31599/jki.v1i1.266. Google Scholar

Syahrul, Y., \& Pertiwi, D. H. (2020). Designing Mobile Based User Interface for Promotion of Lakeur Craft Art Application at Balaputra Dewa State Museum. Journal of Physics: Conference Series, 1500 (1). Google Scholar

Tinggi, P. (2020). Penggunaan Learning Management System (Lms) Di Perguruan. 1 (4), 376-383. Google Scholar

Warin, B, Kolski, C., \& Toffolon, C. (2018). Â€ Cliving Persona Technique Applied To Hci Education, Â€ In Ieee Global Engineering Education Conference. Educon. Google Scholar

Warin, Bruno, Kolski, C., \& Toffolon, C. (2018). Living Persona Technique Applied To Hci Education. Ieee Global Engineering Education Conference, Educon, 2018April, 51-59.Google Scholar

White, P. J., Carlow, T., \& Devitt, F. (2021). Creating Personas From Design Ethnography And Grounded Theory. 16 (3). Google Scholar

Wolf, R. De. (2017). What Project Management System does the Multidisciplinary Team want? A requirement study to compare the users' wishes What Project Management System does the Multidisciplinary Team want? A requirement study to compare the users' wishes with two. Google Scholar

Zagallo, P., McCourt, J., Idsardi, R., Smith, M. K., Urban-Lurain, M., Andrews, T. C., Haudek, K., Knight, J. K., Merrill, J., Nehm, R., Prevost, L. B., \& Lemons, P. P. (2019). Through the Eyes of Faculty: Using Personas as a Tool for LearnerCentered Professional Development. CBE—Life Sciences Education, 18 (4), ar62.. Google Scholar 
Arif Rahman Hidayatullah, Wahyu Andhyka Kusuma

\section{Copyright holder:}

Arif Rahman Hidayatullah, Wahyu Andhyka Kusuma (2021)

First publication right:

Jurnal Syntax Admiration

This article is licensed under:

(c) (i) (?) 